\title{
Crisis of Cultural Identity in Khaled Hosseini's The Kite Runner
}

Ramesh Preasad Adhikary $(\mathrm{PhD})^{1 *}$

\author{
${ }^{1}$ Assistant Professor, Tribhuvan University M. M. Campus, Nepalgunj, Nepal \\ DOI: $10.36347 /$ sjahss.2021.v09i05.006 \\ | Received: 06.04.2020 | Accepted: 17.05.2021 | Published: 24.05.2021
}

*Corresponding author: Ramesh Preasad Adhikary (PhD)

Abstract

Review Article

The novel The Kite Runner by Khaled Hosseini deals with the cultural crisis of the characters. Migration, hybridity, acculturation, transculturation and diaspora are responsible for cultural crisis. It presents the suffering of a Muslim boy named Amir of Afghanistan who had migrated to USA where he finds alone and lacks his cultural performance. The scattered people of USA have accepted multicultural aspects. When they followed American culture, they lost their original native culture. The long living in the foreign land and distract from the native land and contact with other culture resulted in cultural loss. The compulsion for adjustment and contacts with foreign brings loss of pure native culture. When they feel identity crisis, they try to retrieve the native culture.

Key words: Identity, culture, hybridity, acculturation, transculturation, diaspora.

Copyright $(\mathcal{C}) 2021$ The Author(s): This is an open-access article distributed under the terms of the Creative Commons Attribution 4.0 International License (CC BY-NC 4.0) which permits unrestricted use, distribution, and reproduction in any medium for non-commercial use provided the original author and source are credited.

\section{INTRODUCTION}

\section{Cultural Crisis in Khaled Hosseini's The Kite Runner}

The present research focuses on the issue of cultural crisis based on Khaled Hosseini's novel The Kite Runnerpublished in 2003. He tries to sketch cultural hybridity of Muslim people in America. Because of the violence in the Afghanistan, some people migrated to America where they faced many problems related to their cultural identity. Displacement, mimicry, assimilation, transculturation, science and technology, cultural admixture, cultural diversity etc. play the role for loss of cultural root. Identity less, rootlessness, diaspora, feeling of loneliness etc. make search for the cultural root in the book. This novel presents the journey of Muslims to America and the memory of Muslim culture. The question arises like; why they came to America? Why one migrant is unable to remain in pure cultural root?

America is a destination place for immigrants from many countries. Many immigrants stay in U.S for different reasons such as studying, working, or running away from economic or politic crisis, religious conflict and warfare in their homeland. In America, the immigrants come along with their original culture. However, they face many kinds of problems in the host country; they realize that they are different with the local people, by having a different name, physical appearance, culture, ethnicity, and religion among other things. Nevertheless, they have to adopt and develop in the host country. Religion and color, namely complexity of conflict toward friendship and other conflicts that happen in Afghanistan during colonization and post colonization era. It is very different with other writers that most of them tell about alienation, cultural shock, and depression. Hosseini can open the eyes of the readers to know Afghanistan life truly which for a long time is closed from outside. Hosseini wrote about Afghanistan before the Soviet war because that is largely a forgotten period in modern Afghan history. For many people in the west, Afghanistan is synonymous with the Soviet war and the Taliban. Hosseini wanted to remind people that Afghans had managed to live in peaceful anonymity.

Afghanistan officially the Islamic Republic of Afghanistan is a landlocked country that is located in south Asia. Afghanistan is a culturally mixed nation, a crossroads between the East and the West, and has been an ancient focal point of migration. It has an important geostrategical location, connecting South Asia, Central Asia and Southwest Asia. In the 19th century, Afghanistan became a buffer state in "The Great Game" played between the British Indian Empire and Russian Empire. On August 19, 1919, following the third Anglo-Afghan war, the country regained full independence from the United Kingdom over its foreign affairs.Since the late 1970s, Afghanistan has suffered continuous and brutal civil war, which included foreign interventions in the form of the 1979 Soviet invasion of Afghanistan and the 2001 US invasion of Afghanistan, 
in which the ruling Talibangovernment was toppled. Besides, many conflicts reveal namely internal conflict as pressure of repression, ethnic conflict and interreligion conflict that become dominant conflict in Afghanistan society. The economy has suffered greatly from the recent political and military unrest since the 1979 Soviet invasion and subsequent conflicts, while severe drought added to the nation's difficulties in 1998-2001.

This history influences Hosseini to lead the writing of his first novel "The Kite Runner". Because his memories of peaceful pre-Soviet era, Afghanistan is as well as his personal experiences with Afghanistan's Hazara people.The Kite Runner reflects condition of Afghanistan society that becomes major issues such as discrimination, racialism and identity. The other conflicts that appear internal conflict in Amir are ethnic conflict and inter-religion conflict in both of them. As we know, the civil war in Afghanistan caused by ethnic conflict. Afghanistan is ethnically a very diverse country, namely Pashtun, Tajik, Hazara, Uzbek, Aimaq, Turkmen, Baluch, and another small group.In this story, the main characters who undergone those conflicts come from a Pashtun and a Hazara ethnic. The Pashtun is described as an ethnic group that has positive attribute and exclusive, namely high social status, honorable, high class, good appearance and success men.

Besides, the Hazara has negative attribute, namely low social status, poor, low class, physical defect and low job such as waiter, servant and beggar. In this case, the different background in both of them appears the issues of cultural identitywhich Amir also keep his cultural identity until he lives in America. Based on the statement that Amir has internal conflict based on the cultural identity, the writer is interested to analyze the issue of cultural identity in The Kite Runner. This novel presents the different identities based on two separate ethnical positions, Hazara and Pashtun. These identities are given meaning through thelanguage and symbolic through which they are represented. The writer will focus on the main characters, Amir and Hassan. In this research, the writer wants to analyze the issue of cultural identity using the concept of Stuart Hall's Cultural Identity.

Amir, who struggles to find his place in the world because of the aftereffects and fallout from a series of traumatic childhood events, an adult Amir opens the novel in the present-day United States with a vague reference to one of these events, and then the novel flashes back to Amir's childhood in Afghanistan. In addition to typical childhood experiences, Amir struggles with forging a closer relationship with his father, Baba; with determining the exact nature of his relationship with Hassan, his Shi'a Muslim servant; and eventually with finding a way to atone for preadolescent decisions that have lasting repercussions.
Along the way, readers are able to experience growing up in Afghanistan in a single-parent home, a situation that bears remarkable similarities to many contemporary. One of the biggest struggles for Amir is learning to navigate the complex socioeconomic culture he faces, growing up in Afghanistan as a member of the privileged class yet not feeling like a privileged member of his own family. Hassan and his father, Ali, are servants, yet at times, Amir's relationship with them is more like that of family members. And Amir's father, Baba, who does not consistently adhere to the tenets of his culture, confuses rather than clarifies things for Amir.

In the novel, the title The Kite Runner represents the character of Hassan who always runs to catch the fallen kites of Amir. The novel also shows the lack of identity between Amir and his father.Amir finds himself in the materialistic world when he realizes that he was not the son of his Baba to whom he used to love so much. He also finds guilty for not helping his dearest friend Hassan. When he discovers that Baba was not his own father but he was the true father of Hassan who used to be his servant once. He feels that he was betrayed by his father up to now by hiding the great secret of their relation. But Baba has been dead for fifteen years, and there is nothing he can do about the situation. Neither feelings of betrayal nor punishment are enough to redeem Amir. Rescuing Sohrab from Assef is not enough either. Only when Amir decides to take Sohrab to the United States and provide his nephew a chance at happiness and prosperity that was denied to his half-brother does Amir take the necessary steps toward atonement and redemption. The final chapter of The Kite Runner addresses the new guilt that Amir has for what he has done. Amir now turns to both God and his own inner strength to help Sohrab. As a sign of his newfound strength, Amir is able to stand up to the General. And as a sign of his newfound maturity, Amir is able to persevere with Sohrab's silence.Sulekha Sundarshan reviews in International Journal of English Literature and Social Sciences as:

This article intends to depict the fellowship reality in The Kite Runner, a novel byKhaled Hosseini. The truth of the nearby emotions as sibling covers the subject of the story in three viewpoints, a connection design between a sibling and his progression sibling, and the tight bound between an uncle and his progression nephew. Furthermore, there is finding that the social character of various ethnic amongst upper- and lowerclass impact Afghan's society in numerous parts of life. The information was gathered through escalated perusing and information explore were broke down utilizing subjective enlightening strategy. The discoveries demonstrate that the fraternity the truth is clear in the connection of Amir - Hassan, and Amir Sohrab is an impression of fellowship in Afghan's society in the period of contention. Amir's life is highly impacted by Hassan when he was as yetyouthful 
Ramesh Preasad Adhikary., Sch J Arts Humanit Soc Sci, May, 2021; 9(5): 179-187

adolescents in Afghanistan till ended up grown-up and lives as migrant in America. The development of character of various ethnic reinforces the discriminative treatment among the general population.

The conflicts between three central characters dramatize themes of compassion and shame. Amir is a Pashtun, the dominant ethnic group in Afghanistan overcoming, the guilt and shame associated with having witnessed the violent act without intervening.

The Kite Runner remains relevant today because of its insight into Afghan culture and the history of the Taliban. This Islamic fundamentalist group was responsible for the attacks on the World Trade Towers on September 11, 2001, the event that sparked America's invasion of Afghanistan and the beginning of the war on terror. Returning to the Booklist's comment about current events, it's important to remember the role of the Taliban and Afghanistan in contemporary America, especially given the rise of ISIS, the crisis in Syria, and the continuing Middle Eastern conflicts. Coming of age story suitable for adolescents and teens, teachers and parents often disagree. While it may be inappropriate as a school assignment for freshman and sophomores, teachers tend to agree that upper level students react well to the content.

Culturally in the novel there is a kind of gap between the status of Amir and Hassan. The novel also shows the caste division in Afghanistan. Hassan is shown as the poor and lower caste whereas Amir is regarded as higher and rich one. The main target of the novel is to make the Amir as winner of kite competition in which Hassan is the character who is a helper of Amir. In the other hand the novel signifies the cultural aspects of Muslims and American. As an adult boy Amir suffers a lot in America with the memory of his childhood and his own norms and values.

\section{Cultural Crisis in Khaled Hosseini's The Kite Runner}

Crisis is a term to describe a turning point in the course of anything; decisive or trouble a state of affairs involving, great danger or trouble, often one which to result in unpleasant consequences. In this sense crisis refers to any event that is going to lead to an unstable and dangerous situation affecting an individual, group, community, or whole society. Crisis are deemed to be negative changes in the security, economic, political, societal or environmental affairs, especially when they occur abruptly, with little or no warning.Afghanistan is the land of many ethnic groups, which is why the country has so many different cultures yet they are all call themselves proudly an Afghan.The culture of Afghanistan reflects its ancient roots and position as a crossroads for invading ethnic groups and traditions.
The population of Afghanistan includes many different ethnic groups. Afghanistan has been disrupted over the past 25 years by civil wars, invasions, rule of the Taliban, and terrorist activities which have destroyed much of the country's culture, family and tribal connections, thus creating hundreds of thousands of refugees. As a result, it becomes difficult to discuss Afghanistan's culture as many of the traditions and ways of life have been ignored and overturned. However, family and tribal life is resuming, refugees are slowly returning and being resettled, and some of the traditional patterns of life are being re-established.

Afghanistan's ethnically and linguistically mixed population reflects its location astride historic trade and invasion routes leading from Central Asia into South and Southwest Asia. While population data is somewhat unreliable forAfghanistan, Pashtuns make up the largest ethnic group of the population, followed by Tajiks, Hazaras, Uzbek, Aimaq, Turkmen, Baluch, and other small groups. Dari (Afghan Farsi) and Pashto are official languages. Dari is spoken by more than onethird of the population as a first language and serves as a lingua franca for most Afghans, though Pashto is spoken throughout the Pashtun areas of eastern and southern Afghanistan. Tajik and Turkic languages are spoken widely in the north. Smaller groups throughout the country also speak more than 70 other languages and numerous dialects. Afghanistan is an Islamic country. An estimated $80 \%$ of the population is Sunni, following the Hanafi school of jurisprudence; the remainder of the populationand primarily the Hazara ethnic grouppredominantly Shi'a.

Despite the attempts during the years of communist rule to secularize Afghan society, Islamic practices pervade all aspects of life. In fact, Islam served as a principal basis for expressing opposition to communism and the Soviet invasion. Islamic religious tradition and codes, together with traditional tribal and ethnic practices, have an important role in personal conduct and dispute settlement. Afghan society is largely based on kinship groups, which follow traditional customs and religious practices, though somewhat less so in urban areas.Amir and Hassan have tradition according to Islam. In tenth day of DhulHijjah, the last month of the Muslim calendar, and the first of three days of Eid Al Adha, or Eid-e-Qorban, as Afghans call it-a day to celebrate how the prophet Ibrahim almost sacrificed his own son for God. Usually Amir, Hassan and their fathers stand in the backyard to see this ritual every year. Besides, there are some customs in Eid Al-Adha such as divide the meat in thirds, one for the family, one for friends, and one for the poor. Then, the other custom is to not let the sheep see the knife and feed the animal a cube of sugar to make death sweeter. (Hosseini 2003, 67). Besides on Eid, three days of celebration after the holy month of Ramadhan, Kabuli dressed in their best and newest clothes and visited their families. People hugged and kissed and 
greeted each other with Eid Mubarak. Happy Eid. Children opened gifts and played with dyed hard-boiled eggs. In this moment, Hassan gets the gifts from Baba and he plays together with Amir. (Hosseini 2003, 38).

In Afghanistan, yelda is the first night of the month of Jadi, the first night of winter, and the longest night of the year. As was the tradition, Amir and Hassan used to stay up late, their feet tucked under the kursi, while Ali (Hassan's father) tossed apple skin into the stove and told them ancient tales of sultans and thieves to pass that longest of nights. Besides, if the people ate watermelon in the night of yelda, they wouldn't get thirsty the coming summer. In addition, yelda was the starless night tormented lovers kept vigil, enduring the endless dark, waiting for the sun to rise and bring with it their loved one. (Hosseini 2003, 125) Afghans display pride in their religion, country, ancestry, and above all, their independence. Like other highlanders, Afghans are regarded with mingled apprehension and condescension, for their high regard for personal honor, for their clan loyalty and for their readiness to carry and use arms to settle disputes. As clan warfare and internecine feuding has been one of their chief occupations since time immemorial, this individualistic trait has made it difficult for foreign invaders to hold the region. Afghanistan has a complex history that has survived either in its current cultures or in the form of various languages and monuments. However, many of the country's historic monuments have been damaged in recent wars. The two famous statues of Buddha in the Bamyan Province were destroyed by the Taliban, who regarded them as idolatrous.

Cultural Crisis is one of the most used term in postcolonial studies. It commonly refers to an incident that leads to a dangerous situation, affecting individual and society as a whole. Since culture has a varied connotation varying from personal to the collective frame of life, cultural crisis may also appear in different fields like education, politics, human resource management etc. Muslims were migrated to America from Afghanistan. The domination make compelled to Muslim to escape to the U.S.A. Holocaust was a very pathetic for Muslims. They had pain for the loss the native culture but living alive became more important for them. So, they moved to foreign land.

When they came to America, they cannot stay untouched from foreign culture. They had a fear of loss of culture. The period of long time, open easy culture, freedom and lack of continuation make them accept the foreign culture. Migration is forceful or voluntary. This is not a natural process, but one in which great efforts need to be made, sometimes in an effort to maintain one's own culture, but also with regard to the host society. In other words, these migrants differ in their cultural and religious backgrounds, in their migrations, and the extent to which they adapt to local societies.
The process of globalization include massive migrations and relocations, thus challenges the traditional concept of nation-state and opening up borders and boundaries. Bill Ashcroft, Gareth Griffiths, and Helen Tiffin view in The Post-Colonial Studies Reader that the transitional movement of goods, information, and bodies, we need to reconsider the effects of relocation, displacement, and the transition between cultures and how these things affect the construction of identity.

Ashcroft believes that the issues of started to be important after the experience of the colonial invasion:

A major feature of the post-colonial literature is the concern with place and displacement. It is here that the special post-colonial crisis of identity comes into being; the concern with the development or recovery of an effective identifying relationship between self and place. A valid active sense of self may have been eroded by dislocation, resulting from migration, the experience of enslavement, transportation, or voluntary removal for indentured labour.

Ashcroft's view is that identity concerns with the place. Displacement brings identity crisis. Mutual connection of the both cultures, Muslims are ambivalent. Both cultures are basically different but mutual connection between them it seems one contradictory but comfortable.

Reading namaj is the key part of their culture which they have forgotten to recite properly. They have the illusion in the faith towards Allah. They have settled in the country where eating pork and celebrating Christmas is common. But these practices are against Muslim culture. Migration, displacement and dislocation play the role of learning different kind of culture. So, assimilation, acculturation, mimic, of different cultures and celebration of native culture together goes cultural hybridity. On the one hand, it is the opportunity to adopt higher culture. On the other hand, it is the possibility of loss of native culture. Mimicry plays the of cultural hybridity and loss of culture. There is compulsory to adjust with various ethnic groups from different countries. They spent their life as Americans. They have dreams of America to be rich, intelligent, transcendental and rational. They don't believe on superstitious belief on god and religion.

When the Russian invade Afghanistan in 1980s, Amir and Baba flee to America. In America, Amir still remembers about his memories and his guilt toward Hassan in the past. The feeling over of Amir's guilt makes him always fastens upon anything with his mistakes that he has ever done in the past. For example, when Soraya (Amir's wife) does not get pregnant although they endure various fertility program. Amir has opinion that it is God punishment to him. They have chosen to adopt a baby to be their breed later, but 
Ramesh Preasad Adhikary., Sch J Arts Humanit Soc Sci, May, 2021; 9(5): 179-187

adoption process is not an easy matter for Amir and his wife that come from Afghanistan. For Afghan society, if they want to adopt a baby with unknowing breed clearly, it will evoke a problem in the future. Because in society tradition of Afghan race, background and somebody's offspring are very important to detect from which they come and from which ethnic breed they are given. In addition, in Islam law, Shari'a, does not permit adoption even the more moderate Muslim nations.

Finally, Amir can solve his problem by departing for Afghanistan. He departs for Afghanistan with the situation is dangerous, because of many foreign countries and militants enter to Afghanistan. He wants to bring a son of Hassan in the orphanage in Afghanistan. His return to Afghanistan which the dangerous condition shows that Amir has internal conflict deeply, so that, he wants to sacrifice himself to escape from his problems.

For Amir, Afghanistan is like two sides of a coin, namely hating and missing. Those matters melt to become one, namely his willingness to atone his sin and wipe off his guilt. His trip to Afghanistan is to take a part from himself remained and to wipe off all bad memories with a kindness, with rescue a half-nephew, Sohrab grandfather into his own household. (Hosseini 2003, 21). After that, Baba never refers Ali as his friend in Baba's stories. However, in the winter of 1975, the internal conflict which Amir envies toward Hassan happens in both of them that makes their cultural identity is different (superior and inferior). Amir comes from the superior ethnic who always does everything to wipe Hassan off his life like letting Hassan to become a victim of sexual harassment and accusing Hassan of stealing his watch and money. Besides, Hassan comes from the inferior ethnic who always accept everything from the superior ethnic, Amir.

Their cultural identity is very strong that cannot be changed by anything. It can be seen when Hassan always gets the cruelty from superior ethnic, especially from Amir. He cannot against what Amir does toward him. Hassan only accepts it and Hassan also recognizes that he is just a Hazara. He is a minority ethnic group in Afghanistan Hassan identity is like his father, Ali, as a Hazara and Shi'a Muslim. The Hazara kinship is organized in lineages; descent is traced through the male line. The male in specific area consider themselves descendants of common ancestor. I can still see Hassan up on the that tree sunlight flickering through the leaves onhis almost perfectly round face, a face like a Chinese doll chiseled from hardwood: his flat, broad nose and slanting, narrow eyes like bamboo leaves, eyes that looked, depending on the light, gold, green, even sapphire... (49)

Hassan has a round face, a face like a Chinese people. He has broad nose and slanting, narrow eyes like bamboo leaves, eyes that looked, depending on the light, gold, green, even sapphire and tiny low-set ears. His characteristics are Mogul descendants. The Hazara are thought to have several affinities with the Mongols, including physical appearance, language, and kinship system.

Besides, the Hazaras has attribute completely negative, like: low social, poor, low class, has defect in body such as Hassan has harelip and Ali has leg polio, and only move in low job area likes waitress, beggar, and servant like Ali and Hassan as servants. In addition, most Hazaras is illiterate like Hassan and Ali that cannot read the books, because they do not have money to attend school. So, most Hazaras have been decided to illiterate the minute he had born. From that's description, the people have stereotype for the Hazara "Poor and illiterate". Because Hassan has negative attribute, the other boys have epithet name to Hassan such as Flat-Nose, A loyal Hazara, Loyal as a dog. This case shows that Hassan is inferior that always accepts everything from the other. Never mind any of those things. In the end I [Amir] was a Pashtun and he was a Hazara, I [Amir] was Sunni and he was Shi'a, and nothing was ever going to change that. Nothing. (22) Amir recognizes his identity as a Pashtun and Sunni Muslim. His identity cannot be changed by anything, because history is not easy to overcome. Amir as a Pashtun is different with the other boys especially his servant, Hassan, a Hazara in physical appearances, religion, ethnicity and personality. The differences make him as superior, better class in Afghanistan. Besides, it can be seen from the different in his physical appearances with the other as in this quotation.

Since the novel "The Kite Runner" published in 2003, it becomes able to attract the attention of many critics and scholars. The novel appears to the tragedy of war, condition of immigrants in foreign land and lack of tradition and culture. Betrayal, which can be considered a form of sin, is enduring and ends up being cyclical in The Kite Runner. For most of the novel, Amir attempts to deal with his guilt by avoiding it. The Kite Runner also alludes to the differences between European and Western Christian cultures on the one hand, and the culture of the Middle East on the other. And the conservative Taliban, which outlaws many customs and traditions, also demonstrates the differences within the same religious groups A gripping and emotional story of betrayal and redemption, The Kite Runner had me thrilled and moved, both at the same time. It tells the story of Amir and Hassan, the closest of friends, as good as brothers, and also experts in the art of kite flying. The two young boys live in Kabul, the capital of Afghanistan, and this year they are going to try harder than ever to win the local kite-fighting tournament-a popular Afghan pastime and this is Amir's one hope of winning his father's love. But just like the kites battling in the sky, war comes to Afghanistan, and the country becomes an extremely dangerous place. 
In war, people are often forced to make great sacrifices, and the young Amir himself commits an act of betrayal, towards his best friend Hassan no less, which will haunt him for the rest of his life. Amir and his father are forced to flee Afghanistan for America, and The Kite Runner becomes the story of Amir's quest for redemption - righting the wrongs he committed all those years ago as a boy in Kabul.

The story is fast-paced and hardly ever dull, and introduced a world, the world of Afghan life, which is strange, fascinating and yet oddly familiar all at the same time. Hosseini's writing finds a great balance between being clear and yet powerful, and not only is the story itself brilliantly constructed, but the book also explores the very art of storytelling. Amir himself becomes a writer, and he reflects on his experiences in the story as though his life itself were a piece of fiction.

But the best thing about The Kite Runner is its sense of fate and justice, of good overcoming evil in the end, despite all odds. Without giving away the ending, Amir ends up back in Afghanistan and makes a very different set of sacrifices in order to set things straight. The message behind the very ending could be interpreted differently by different readers, it offers a small sense of hope for both the future of its characters, and perhaps for war-torn Afghanistan as well. While this has meant increased government surveillance and hostility, 9/11 has also opened up a new space for Muslims to distance themselves from foreign influences and stake their claim as full-fledged Americans. Attempts to define a uniquely American brand of Islam, however, in fact began twenty odd years ago as immigrants from Muslim countries who arrived in the mid-1960s increasingly began to think of the US as home. This novel focuses on Muslim American selfperception and self-representation.

On the eve of the lifting of the 1965 quota laws that paved the way for Muslims to become a major immigrant group to the United States, American Muslims were for the most part descendants of the small numbers of immigrants from the Ottoman Empire and the Middle East who had arrived during the great immigration wave of the late nineteenth and early twentieth centuries. These descendants followed a process of integration and acculturation not different from that of the much larger numbers of Poles, Italians, and Eastern European Jews who arrived during the same period. It was in the 1950 s and early 1960 s, when identification with a religious community was increasingly designated as a necessary component of Americanism that the first wave of mosque-building began in the United States. It was their children's questions about their own religious heritage, the founders of these early mosques often recall, that provided the necessary spark for the creation of mosques in those communities with enough Muslims to support them. These early mosques were intended first and foremost as a vehicle of integration into American society and adapted to American social and cultural norms of the day. Men and women, often with uncovered heads, prayed together more often than not, and mixed-gender events for young people, including Halloween parties and Valentine's Day dances took place regularly in the social hall of the mosque basement.It was in 1965, when the quota system privileging immigrants from Northern Europe was lifted, that these small Muslim communities began to be overwhelmed by a much more substantial wave of Muslim immigrants from Southern Asia and the Middle East.

The ideological orientation and demographic profiles of these new immigrants were very different from those of the first wave. The first post-1965 arrivals were students and young professionals from India and Pakistan. Most of them, especially those who were religious in orientation, planned on returning home once their education was completed. As a result, integration into American society was initially not an issue of communal concern. Furthermore, these immigrants had been influenced by the Islamic revival of the postColonial era, and the religiously inclined among them tended to think of the West as "dar el harb" (the land of war), a place where Islam could never take root and flourish. The influence of this "re-Islamization" of the Muslim world was even stronger in the 1970s and 1980s, as immigration from Southern Asia and the Middle East became more important. During this era, dubbed by one scholar of the contemporary Islamic world as the age of the "the ascendancy of Islamic ideologies," a wide variety of competing religious and socio-cultural movements-from the Islamic Brotherhood to Saudi Arabian Wahabism and advocates of the brand of political Islam that formed the ideological basis of the Iranian Revolution-promoted Islam as a moral and ethical system that stood in contrast to degenerate Western values and hence provided the answer to rebuilding a strong, independent post-colonial Muslim world.The influence of these cultural paradigms meant that those new immigrants who actively identified with Islam were often shocked by the Americanized brand of Muslim culture that they found upon their arrival. The small existing MuslimAmerican communities often came into conflict with these new arrivals, and the newcomers' much stronger numbers meant that their own conservative, assertive brand of Islam soon prevailed. The fact that Muslims began arriving in the United States in substantial numbers during the cultural revolution of the 1960s and 1970s, when parental control over teenagers was loosening, recreational drugs became popular, and taboos against pre-marital sex were falling away, also created a larger gap between behaviors deemed acceptable for young people in the United States and traditional cultural and sexual norms in the Muslim world. 


\section{Development of New Identity}

Khaled Hosseini's novelThe Kite Runner deals with the issue of immigration, displacement, acculturation, assimilation, mimicry, effect of science and technology, mutual relationship, cultural admixture and in-between space on the one hand. And on the other hand, it deals the issues of diaspora, identity crisis, nationalism, rootlessness etc. It is the history of the American Jews who migrate to America when there was holocaust in Europe. Emigrant Muslims have their native culture which mingles with different types of American culture. Getting admixture with American culture Jews lose their pure native culture. But they cannot forget completely. Bend toward the both cultures they are in-between. Existences of both cultures appear a third new culture which is called hybrid culture.

Identity are the interface between a private sense of self that includes conscious and unconscious feelings, rational and irrational motivations, personal beliefs and values and those factors that constitute the social context in which we experience those feelings and motivationsfor example age, ethnicity and sex. Everybody lives in different countries in the world, with different cultures, religions, personality's even ethnicities. These differences become his or her identity in society when they are interacting with one another. And identity is used to know the social status, such as races, ethnicity, sexual orientation, marital status, etc.

Besides, Cultural Identity belongs to a particular ethnic group and how that influence one's feeling, perception, and behavior. Cultural Identity is that part of a person's self-concept that comes from the knowledge and feelings about belonging to a particular cultural group. From those definitions, it can be concluded that Cultural Identity is one's feeling belongs to particular ethnic group. This matter also explains that sense of belonging is an important factor in forming identity.

Besides, the strength of our cultural identities involves the degree to which we see our culture as important in the way we define ourselves. We tend to see our cultures as important in how we define ourselves. We are in another culture than when we are in our own cultures. We are more aware of our cultural identities when we found ourselves in another culture than when we are in our own culture. Addition, based on the problem that is Amir tries to apply his original culture (Pashtun) in his host country (America) in his family like his father (Baba) wants his culture still exists although they are in America. Because of that the suitable theory will be Diaspora.

According to Stuart Hall, Diaspora does not refer us to those scattered tribes whose identity can only be secured in relation to some sacred homeland to which they must at all costs return. And also, he said that Diaspora defined, not by essence or purity, but by the recognition of necessary heterogeneity and diversity; by a conception of 'identity' which lives with and through, not despite, difference; by the hybridist.That now says the cultures are hybrid, difference and diversity, because of that it is so hard to find the pure one. Diaspora identities are those which are constantly producing and reproducing themselves a new, through transformation and difference. It means that when they are at the other country they still stick with their culture and try to develop through transformation constantly.

To find what can material culture tells about Diaspora, it is important to learn much about the relationship between people and their possessions through this study. The sentimental and emotional attachment to objects is very strong in people's motivation and desires to obtain and maintain certain objects in their possession. These motivations are combined with several outside factors, including economics and pressures from those within and outside of one's family or ethnic, religious, or socioeconomic group to produce of pattern of consumer choice that is riddled with.

The Kite Runner is a novel written by Khaled Hosseini, one of famous Afghanistan American authors. The situation of Afghanistan American inspired him to write The Kite Runner. It tells about someone who runs to catch a kite. The kite is struggle source among Amir, Hassan and Assef as a trophy of honor. It is a symbol of victory for the Afghan boys in Afghanistan. When they succeed to cut the last kite that fly in the air, their victory is incomplete yet because they have to run and get the last kite. In this story, the boy who can run and get the last kite is Hassan. For Amir, Hassan is the best runner in every kite tournament.

The first thing, the writer analyzes in this research is the two main characters in the novel, Amir and Hassan. Their character have important role in development of the story, because they are performed with the conflict through their dialogues and actions that build the story in this novel. Besides, the writer also analyzes their cultural identity because they have different cultural identity even they come from the same country, Afghanistan. It has the purpose to find out the issue of cultural identity in both of them. Their cultural identities influence their life that creates many conflicts such as internal conflict, ethnic conflict and interreligion conflict. The first character is Amir. Amir comes from the richest family and the reputable family in Kabul. He is a pashtun and Sunni Moslem. A Pashtun is majority ethnic group and superior ethnic in Afghanistan that always does cruelty toward the minority ethnic group. His father is successful man. Besides, his mother is literature lecturer. However, Amir lives with his father and Baba's friend, Rahim Khan because his mother died after giving birth him. When Hassan becomes a victim of racialism and 
discrimination that happen in Afghanistan, Amir could not defend him. It makes Amir undergoes an insomniac and feel guilty until he lives in America and becomes a great writer. When Amir does not get a baby, Amir thinks that this is his punishment to him from his mistake in the past toward Hassan.

The second character is Hassan. He is a Hazara and Shi'a Moslem. His identity has stereotype as 'poor' and illiterate. Hassan comes from poor family because his half-father, Ali, is a servant in Amir's house. Then, he grows up illiterate and harelips. The Hazaras in Afghanistan have negative attribute from the other ethnics group such as low job, poor, defect in body such as Hassan. His identity make him always becomes a victim of discrimination and racialism from the Pashtun and the Taliban. So, the Hazara is inferior ethnic in Afghanistan. Amir and Hassan have the cultural identity that is stable and cannot be changed by anything. Hassan always accepts anything from the Pashtun. Then Amir still sticks his cultural identity even Amir lives in America. He undergoes Diaspora like he wants to marry. He chooses a woman that comes from the Pashtun. He wants to keep alive his ancient standard of pride and honor. Then he uses the Afghan wedding and he does not adopt a son from other breed.

The hybrid characters in the novel, Amir and the American Muslims have lost the native identity. The context of the migration in foreign land, a minority group cannot continue purely. On the one hand, they have adopted foreign culture or they have their own native culture. The adoption of the foreign culture practicing the native culture together. On the way, Paul Cowan is in ambivalent situation. So, American and Muslim cultural identity accepted by him. Amir says, "I had always identified myself an American Muslim". Cowan's identity is connected to both culture. Inbetween the both culture appears new identity which is called third space. It is result of cross-cultural exchange of multicultural identity. Existence of multiple cultural identities is hybrid cultural identity.

Post-colonial thinkers; Homi K.Bhabah, Bill Ashroft,Gareth Griffiths, Helen Tiffin, Gilroy, Hoogvelt etc. take the theme is concerned with hybridity; the theoretical introduces terms like "Third Space" or "inbetween space", which he describes as a space between two cultures, a kind of compromise between them; a space which does not belong to either of the cultures but can be seen as a common ground for understanding between cultures. Bhabha's theory is, however, confirmed in Cowan's novel. The character Paul Cowan, his grandparents and Jews in America have multiple identities; they are neither seemed Jews nor American but American Jews. "American Jews" is third identity, whom is in-between the American and Jews culture.
The book deals the history of holocaust. At the time, Muslims were escaping to the USA to be saved from persecution. Muslim terrorists were dominating, killing, persecuting cruelly. This research gives information how happens adoption, forgetting, mingling, assimilation, acculturation, hybridity of cultures. Amir forgets his culture because of cultural discontinuation, mimicry, displacement, science and technology in America. Whatever, his/their identity was in native land it negotiate the difference other culture. His/their identity becomes hybrid.

The place and displacement explores terms like "lack of fit" which explains the discrepancy between places and culture used to describe the place. Another view on the connection between place and displacement is connected with dislocation of people. Both these theories explored in Hosseini's novel and are in accordance with the theoreticians who believe in close connection between place and identity. While the connection between place and language is related to share culture, the relationship between place and displacement is associated with personal and group identity. In native land, their identity was 'Jew' but in America their identity is 'American Muslim'.

Most of these studies have approached hybridity as a by-product of the transcultural dynamics between tradition and modernity sometimes conceptualized as the local and the global. Our identity emerges out of our habits. People do not bear with preset beliefs. Every belief, including those about ourselves, is learned and conditioned through experience.

More precisely, our habits are how we embody our identity. When we make our bed each day, we embody the identity of an organized person. When we write each day, we embody the identity of a creative person. When we train each day, we embody the identity of an athletic person.

Of course, our habits are not the only actions that influence our identity, but by virtue of their frequency they are usually the most important ones. Each experience in life modifies our self-image, but it's unlikely we would consider our self a soccer player because we kicked a ball once or an artist because we scribbled a picture. As we repeat these actions, however, the evidence accumulates and our self-image begins to change. The effect of one-off experiences tends to fade away while effect of habits gets reinforced with time, which means our habits contribute most of the evidence that shapes our identity. In this way, the process of building habits is actually the process of becoming our self. 


\section{CONCLUSION}

Displacement, mimicry, assimilation, acculturation, arrival of science and technology, globalization etc. are the factors play the role of loses root culture. Diaspora, identity crisis, rootlessness, nationalism plays the role of retrieving the root culture. Existence of the both cultures, their identity is hybrid. Hybrid identity is neither foreign nor native but producing something familiar but new identity. Khaled Hosseini, by challenging the contemporary theories on postcolonial writing presents to the readers the issues of everyday realities faced by many people from postcolonial countries. Amir and American Muslims cannot be understood as stereotypes which are followed by all people in the same situation but should be understood as an attempt to bring understanding for people who are challenged by the influences of various cultures.

\section{REFERENCE}

1. Ashcroft, B. (2001). Postcolonial Transformation. London: Routledge.
2. Gilroy, P. (2000). Against race: Imagining political culture beyond the color line. Harvard University Press.

3. Ethnicities, N. (1996). Critical Dialogues in Cultural Studies. Ed. David Morely and KuanHsing Chen. Routledge.

4. Hoogvelt, A. (1997). Globalization and the Postcolonial World: The New Political Economy of Development. Baltimore: The John Hopkins University Press.

5. Khaled, H. (2003). The Kite Runner. United States, Red Head Books Press.

6. Potok, C. (1983). Paul Cowan with an afterword by Rachel Cowan. Jewish Lights, New York.

7. Sahoo, A. K. (2006). Issues of identity in the Indian diaspora: A transnational perspective. Perspectives on Global Development \& Technology, 5(1/2), 8198

8. Sudershan, S. (2004). A review of cultural crisis, The Guardians. 